JOURNAL OF RESEARCH of the National Bureau of Standards - A. Physics and Chemistry

Vol. 78A, No. 4, July-August 1974

\title{
The System $\mathrm{NaCl}-\mathrm{AlCl}_{3}$
}

\author{
Ernest M. Levin \\ Institute for Materials Research, National Bureau of Standards, Washington, D.C. 20234 \\ and \\ J. F. Kinney, * R. D. Wells, * and J. T. Benedict \\ Fairleigh Dickinson University, Teaneck, New Jersey 07666
}

(March 14, 1974)

\begin{abstract}
The system NaCl- $\mathrm{AlCl}_{3}$ has been restudied by DTA, visual observation, and x-ray diffraction powder techniques for identification of crystalline phases. It was confirmed that the system contains one intermediate compound $\mathrm{NaAlCl}_{4}$ with an incongruent $\mathrm{mp}$ of $153 \pm 0.5{ }^{\circ} \mathrm{C}$ and a region of liquid immiscibility extending from 80.25 to 99.6 mol percent $\mathrm{AlCl}_{3}$ at $191.3^{\circ} \mathrm{C}$, the monotectic temperature.
\end{abstract}

Key words: Immiscibility; $\mathrm{NaAlCl}_{4}$; phase equilibrium; system $\mathrm{AlCl}_{3}-\mathrm{NaCl}$; system $\mathrm{NaCl}-\mathrm{AlCl}_{3}$.

\section{Introduction}

A summary of the pertinent data in previous studies $[1-5]^{1}$ of the system is given in table 1 . In addition, Boud [6] in 1904 reported compound compositions of $3 \mathrm{NaCl} \cdot \mathrm{AlCl}_{3}, \mathrm{NaCl} \cdot \mathrm{AlCl}_{3}$, and $\mathrm{NaCl} \cdot 2 \mathrm{AlCl}_{3}$. The compound $\mathrm{NaAlCl}_{4}$ with an incongruent melting point at $\sim 153{ }^{\circ} \mathrm{C}$ seems well established and its crystal structure has been determined [7], using a Weissenberg camera. It is orthorhombic (space group P $2{ }_{1} 2_{1} 2_{1}$ ), with $Z=4$ and $d$ (x-ray) $=2.00 \mathrm{~g} / \mathrm{cm}^{3}$. However, the existence of additional compounds and the occurrence of a stable two liquid region of immiscibility are questionable.

\section{Experimental Procedure}

The general nature of the diagram was first established with a commercial DTA apparatus ${ }^{2}$, using a microholder with $\mathrm{Al}_{2} \mathrm{O}_{3}$, as a reference material and a $10 \%$ min heating rate. The final diagram (fig. 1) was refined by determining the liquidus and solidus curves by visual observation. The chlorides of aluminum and sodium were obtained as Reagent Grade. The $\mathrm{NaCl}$ was analyzed to be $99.7 \pm 0.1$ percent pure. The $\mathrm{AlCl}_{3}$ was resublimed at $135-150{ }^{\circ} \mathrm{C}$ under vacuum from

\footnotetext{
*Now with Avon Products Inc., Research and Development Division, Suffern, New York 10901.

${ }^{1}$ Figures in brackets indicate the literature references at the end of this paper

${ }^{2}$ Certain commercial materials and equipment are identified in this paper in order to adequately specify the experimental procedure. In no case does such identification imply recommendation or endorsement by the National Bureau of Standards, nor does it imply that the material or equipment identified is necessarily the best available for the purpose.
}

molten $\mathrm{NaCl} \cdot \mathrm{AlCl}_{3}$ mixtures containing Al-metal strips [8]. The final purity of $\mathrm{AlCl}_{3}$ was analyzed to be $99.8 \pm 0.1$ percent. Atomic absorption analysis for $\mathrm{Na}$ confirmed a content of $<0.1$ percent $\mathrm{Na}$ in the $\mathrm{AlCl}_{3}$. To prevent hydration of $\mathrm{AlCl}_{3}$, various mixtures of $\mathrm{NaCl}$ and $\mathrm{AlCl}_{3}$ were prepared in glove bags flushed with anhydrous $\mathrm{N}_{2}$ and sealed under vacuum in Pyrex tubes. Compositions not forming two liquids, i.e., those below 80 mol percent $\mathrm{AlCl}_{3}$, were subjected to three cycles of grinding and sealing in the glove box, followed by heating to promote homogeneity. Samples which had been reground several times appeared pure white in color; but when they were heated to the appropriate invariant temperature of either 153 or $107^{\circ} \mathrm{C}$, they turned sharply to a gray hue.

The two liquid region of the diagram was studied visually by introducing the sealed sample into a nichrome-wound Pyrex tube furnace $(40 \mathrm{~mm}$ O.D.) insulated by an outer Pyrex tube. Sealed samples with 80 mol. percent $\mathrm{AlCl}_{3}$ and less were studied visually in a silicone oil bath, stirred with a magnetic stirrer. Heat control was accurate enough to permit heating and cooling rates of $6{ }^{\circ} \mathrm{C}$ per hour or less. The liquidus temperatures were determined by observing under a magnifying glass the disappearance of tiny crystals approximately $0.5 \mathrm{~mm}$ in their largest dimension. Several determinations were averaged, and all temperatures are estimated accurate to $\pm 0.5{ }^{\circ} \mathrm{C}$. The Chromel-Alumel thermocouple was calibrated using pure $\mathrm{Sn}\left(\mathrm{mp} 231.89^{\circ} \mathrm{C}\right)$ and the normal freezing and boiling points of water. At times a calibrated $\mathrm{Hg}$ thermometer was used also in the oil bath. 
TABLE I. Phase studies in the system $\mathrm{NaCl}-\mathrm{AlCl}_{3}$

\begin{tabular}{|c|c|c|c|c|c|c|c|}
\hline \multirow{3}{*}{ Investigator } & \multirow{3}{*}{ Methods of Study } & \multirow{3}{*}{$\frac{\begin{array}{c}\text { Incong. mp of } \\
\mathrm{NaAlCl}_{4}\end{array}}{{ }^{\circ} \mathrm{C}}$} & \multirow{2}{*}{\multicolumn{2}{|c|}{$\begin{array}{c}\text { Location of } \mathrm{NaAlCl}_{4}-\mathrm{AlCl}_{3} \\
\text { Eutectic }\end{array}$}} & \multicolumn{2}{|c|}{ Two Liquid Region } & \multirow[b]{3}{*}{ Notes } \\
\hline & & & & & \multirow{2}{*}{$\begin{array}{c}\text { Extent } \\
\mathrm{Mol} \% \mathrm{AlCl}_{3}\end{array}$} & \multirow{2}{*}{$\begin{array}{l}\text { Temp. } \\
{ }^{\circ} \mathrm{C}\end{array}$} & \\
\hline & & & $\mathrm{Mol} \% \mathrm{AlCl}_{3}$ & Temp. ${ }^{\circ} \mathrm{C}$ & & & \\
\hline $\begin{array}{l}\text { Kendall, et al. } \\
\text { (1923) [1] }\end{array}$ & $\begin{array}{l}\text { Visual observation } \\
\text { in sealed tubes }\end{array}$ & 152 & $\sim 61$ & 115 & $82.0->99.8$ & 193.5 & $\begin{array}{l}\text { Compound } \mathrm{XNaCl} \text {. } \\
\mathrm{YAlCl}_{3} \text { under two } \\
\text { liquids. }\end{array}$ \\
\hline $\begin{array}{l}\text { Plotnikov and } \\
\text { Shvartsman } \\
\text { (1936) [2] }\end{array}$ & $\begin{array}{l}\text { Heating and cool- } \\
\text { ing curves auto- } \\
\text { matically re- } \\
\text { corded; sealed }\end{array}$ & - & 61 & 108 & & & $\begin{array}{l}\text { Only studied be- } \\
\text { tween } 50.2 \text { and } \\
80.8 \text { mol \% } \mathrm{AlCl}_{3} \text {. }\end{array}$ \\
\hline $\begin{array}{l}\text { Shvartsman } \\
\quad(1940)[3]\end{array}$ & $\begin{array}{l}\text { Heating and cool- } \\
\text { ing curves auto- } \\
\text { matically re- } \\
\text { corded, sealed }\end{array}$ & 152 & 61 & 108 & $80.8-100$ & 190.0 & \\
\hline $\begin{array}{l}\text { Cretien and } \\
\text { Lous (1943) } \\
{[4]}\end{array}$ & $\begin{array}{l}\text { Cooling curves in } \\
\mathrm{N}_{2} \text { atm; Chem. } \\
\text { analysis }\end{array}$ & 155 & 65 & 105 & None detected & & \\
\hline $\begin{array}{l}\text { Midorikawa } \\
\text { (1955) [5] }\end{array}$ & Cooling curves & 154 & 62 & 112 & & & $\begin{array}{l}\text { Only studied be- } \\
\text { tween } 48.1 \text { and } \\
70.7 \text { mol } \% \mathrm{AlCl}_{3} \text {. }\end{array}$ \\
\hline Present study & $\begin{array}{l}\text { DTA; visual ob- } \\
\text { servation in } \\
\text { sealed tubes; } \\
\text { x ray }\end{array}$ & $153 \pm 0.5$ & 61.4 & 107.2 & $80.25-99.6$ & 191.3 & \\
\hline
\end{tabular}

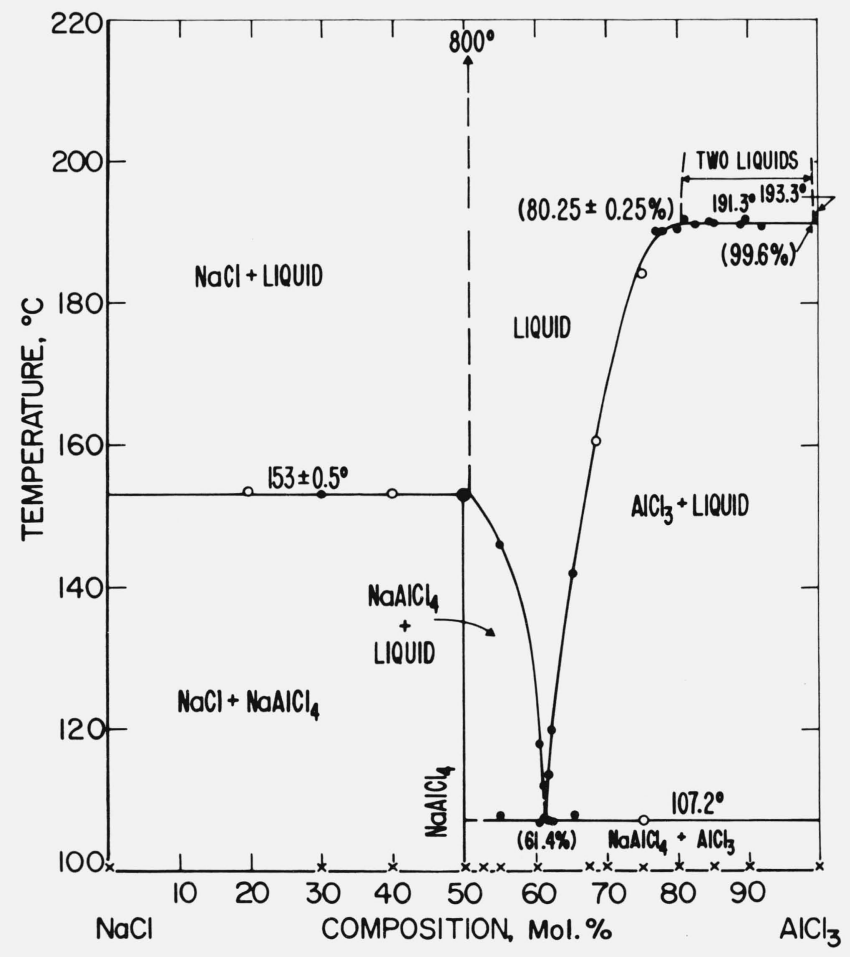

Figure 1. The system $\mathrm{NaCl}-\mathrm{AlCl}_{3}$.

o-Visual observation.

$\mathrm{O}-\mathrm{DTA}$

$\mathrm{X}$ - X-ray examination at room temperature.
The solid phases were identified by x-ray diffraction powder techniques, using a dry mount with $\mathrm{Mg}\left(\mathrm{ClO}_{4}\right)_{2}$ as desiccant. All compositions could be interpreted in terms of the components $\mathrm{NaCl}$ and $\mathrm{AlCl}_{3}$, and one intermediate compound $\mathrm{NaAlCl}_{4}$. The $\mathrm{x}$-ray powder pattern of $\mathrm{NaAlCl}_{4}$ was indexed on the basis of an orthorhombic cell [7], with $a=10.33 \AA, b=9.91 \AA$, $c=6.18 \AA$, within a few hundreths Angstroms of the dimensions reported by Baenziger [7] and Semenenko et al. [9]. Small irregular variations in interplanar spacings with different compositions are attributed to hydration effects rather than to an indication of slight solid solubility of $\mathrm{AlCl}_{3}$ in $\mathrm{NaAlCl}_{4}$.

A two liquid region, as reported by Kendall et al. [1], and Shvartsman [3], was found to exist between a composition of $80.25 \pm 0.25$ and 99.6 mol percent $\mathrm{AlCl}_{3}$ at $191.3{ }^{\circ} \mathrm{C}$. Two liquids were observed visually to form in several samples containing $80.5 \mathrm{~mol}$ percent $\mathrm{AlCl}_{3}$ or greater (fig. 1). In repeated experiments, two liquids were never observed in samples of 80.0 mol percent $\mathrm{AlCl}_{3}$ or less, i.e., 79.5, 77.9, and 75 percent. Atomic absorption analysis for $\mathrm{Na}$ in the upper liquid segregated at $\sim 192{ }^{\circ} \mathrm{C}$ revealed the composition to be $0.4 \mathrm{~mol}$ percent $\mathrm{NaCl}$. The composition of the $\mathrm{AlCl}_{3}$-rich liquid, therefore, is $99.6 \mathrm{~mol}$ percent $\mathrm{AlCl}_{3}$.

Several attempts were made to study the closure of the two-liquid dome. Samples of composition 80.6 and $90.2 \mathrm{~mol}$ percent $\mathrm{AlCl}_{3}$ were heated in sealed glass tubes to form two liquids. After heating at a rate of $5{ }^{\circ} \mathrm{C} /$ day and reaching temperatures of above 
$210{ }^{\circ} \mathrm{C}$, the tubes burst. The triple point of $\mathrm{AlCl}_{3}$ is reported [10] at $193.3{ }^{\circ} \mathrm{C}$ and $2.33 \mathrm{~atm}$.

\section{Conclusion}

In conclusion, a restudy of the system $\mathrm{NaCl}-\mathrm{AlCl}_{3}$ has shown it to contain only one intermediate compound and a definite region of liquid immiscibility. Also, temperatures and compositions of invariant points have been closely defined.

\section{References}

[1] Kendall, J., Crittenden, E. D., and Miller, H. K., J. Am. Chem. Soc. 45, 963 (1923); also, Fig. 3107 in Phase Diagrams for
Ceramists, published by the Am. Ceram. Soc., Inc. (1969).

[2] Plotnikov, V. O., and Shvartsman, U. I., Western Inst. Chem., Akad. Nauk URSR 3, 387 (1936).

[3] Shvartsman, U. I., Western Inst. Chem., Akad, Nauk URSR 7, 1 (1940); also, Fig. 1314 in Phase Diagrams for Ceramists, published by the Am. Ceram. Soc., Inc. (1964).

[4] Chrétien, A., and Lous, E., Compt. Rendu 217, 451 (1943).

[5] Midorikawa, R., J. Electrochem. Soc. Japan 23, 72 (1955).

[6] Boud, A., Ann. Chim. Phys. 1, 8 (1904).

[7] Baenziger, N. C., Acta Cryst. 4, 216-19 (1951).

[8] Uhr, D., Master's Thesis, 1970, Fairleigh Dickinson Univ., Teaneck, N.J. 07666.

[9] Semenenko, K. N., Surov, V. N., and Kedrova, N. S., Russ. J. Inorg. Chem. (English Transl.) 14, [4] 481-83 (1969).

[10] Treadwell, W. D., and Terebesi, L., Helv. Chim. Acta 15, 1053-66 (1932).

(Paper 78A4-830) 